Agro-Science Journal of Tropical Agriculture, Food, Environment and Extension Volume 8 Number 2 May 2009 pp 116-120

ISSN 1119-7455

\title{
EVALUATION OF FRUIT AND BUNCH TRAITS IN BLACK SIGATOKA RESISTANT PLANTAIN AND BANANA HYBRIDS
}

\author{
Adeniji, Tajudeen Adebayo $^{1}$, Barimalaa, Iminabo Samuel ${ }^{2}$ and Tenkouano, Abdou ${ }^{1}$ \\ ${ }^{1}$ International Institute of Tropical Agriculture, P.M.B. 5320, Oyo Road, Ibadan, Nigeria. \\ ${ }^{2}$ Department of Food Science and Technology, Rivers State University of Science and \\ Technology, P.M.B. 5080, Nkpolu, Port Harcourt, Nigeria.
}

\begin{abstract}
Studies involving the evaluation of fruit and bunch characteristics of twenty seven cultivars of plantain and banana were undertaken. Results showed that bunch weight of plantain hybrid, 25344-18, differed significantly $(P<0.05)$ from all other genotypes except $S H 3362$, with an average of $20.8 \mathrm{~kg}$ plant ${ }^{1}$. The number of hands and fruits bunch ${ }^{-1}$ for 9128-3, SH 3362, 25291-S32 and 25344-18 were significantly different $(P<0.05)$ from plantain landraces (Agbagba and Obino l'Ewai). Agbagba differed significantly $(P<0.05)$ from the rest of the genotypes both in fruit weight and fruit volume. There was a high significant difference $(P<0.05)$ in fruit weight and fruit volume between a banana hybrid, 5295-1, and all other hybrids, and Obino l'Ewai. Highly significant positive correlation $(P<0.01)$ was observed between bunch weight and the number of hands, number of fruits bunch ${ }^{-1}$, as well as fruit volume. The same trend was observed in the number of hands bunch $^{-1}$ and number of fruits hand, and also between fruit weight and fruit volume. A high negative correlation $(P<0.01)$ was observed between number of fruits and fruit weight and volume. There was no correlation between number of hands and fruit weight, and number of hands and fruit volume. These findings suggest that new Musa hybrids are highly promising in terms of yield and certain fruit and bunch traits and could therefore complement African traditional plantains.
\end{abstract}

Key words: Black Sigatoka resistant, hybrid, evaluate, yield components, post harvest.

\section{INTRODUCTION}

The main centres of plantain and banana cultivation in Africa are the wet tropical zones of West and Central Africa and the East African Highlands (IPGRI, 1999). World production of plantain is approximately 24 million tons of which 17 million tons representing $70.8 \%$ are produced in Africa (FAO, 1987). The overriding constraints to plantain and banana production are decreasing soil fertility, yield decline phenomenon, pest (weevils and nematodes) problems and most importantly, the widespread leaf spot disease called black Sigatoka (IITA 1992; Stover and Simmonds, 1987). Mycosphaerella musicola Leach and Mycosphaerella fijiensis are respectively the casual agents of yellow Sigatoka and black Sigatoka in Musa (Fullerton, 1994). Black Sigatoka is a virulent air borne fungal leaf spot disease, which can reduce plantain yield by up to $30-50 \%$ (Stover, 1983; INIBAP, 1987). The fungal pathogen, Mycosphaerella fijiensis Morelet, attacks the leaves, causing severe defoliation by leaf necrosis (Stover, 1983).

The International Institute of Tropical Agriculture (IITA) has acknowledged that black Sigatoka disease is the most critical research issue for plantain and banana in Africa. The Plantain and
Banana Improvement Programme was established by IITA following the identification of black Sigatoka disease of plantain in 1986. Consequently, plantain was added to the institute's list of mandated crops in 1987 and plans to combat black Sigatoka through both short-term and long-term strategy was initiated (IITA 1988). The short-term agenda consists of the identification, rapid in vitro multiplication, and distribution of black Sigatoka-resistant cooking bananas (Musa spp., ABB group) from Southeast Asia to farmers in the worst affected areas (Hahn et al., 1990; Ferris et al., 1994). Based on the experience of IITA banana breeding programme, the second approach, which involves breeding for resistant genotypes was anticipated to be a long-term project. This involves the breeding for black Sigatoka resistance hybrids. To this end, IITA have bred many cultivars of Musa hybrids which combines high yield with disease resistance. Tetraploid hybrids that are derived from different crosses produced heavier bunch compared to their parents (Vuylsteke et al. 1997). However, the introgression of genes of bananas may alter fruit quality characteristics in the hybrids, which may in turn affect consumer acceptability. Some of 
Fruit And Bunch Traits in Black Sigatoka Resistant Plantain and Banana Hybrids

the newly developed hybrids are currently undergoing field trials in multi-ecological locations through the National Agricultural Research and Extension Systems (NARES) in Nigeria. Research is therefore required to examine the yield and post harvest traits in the new hybrids to ensure successful introduction of the new hybrids to the end users.

Most producers and consumers of plantain and banana usually prefer large size bunches with large or small size fruit and/or long or short fruit, depending on the locality or country (Dadzie and Orchard, 1997). Therefore, assessment of bunch weight and fruit characteristics is important post harvest selection criterion. Bunch weight and number of hands per bunch (Stover and Simmonds, 1987) are important pomological characteristics from the standpoint of quality specifications. The number of fruits per hand is fairly constant from the fourth to the last hand, while fruit grade and finger length decrease linearly from the fourth to the last or apical hand (Stover and Simmonds, 1987). The size and weight of fruits are important parameters in determining their marketability. Fruit physical measurements such as bunch traits (weight and number of hands per bunch) are used to evaluate yield and response to experimental treatments (Stover and Simmonds, 1987). In addition, screening of new Musa hybrids for their fruit characteristics at harvest may be important in the design of packaging for the fruit, which would enhance efficient handling and transportation (Dadzie and Orchard, 1997). The objective of this present study was to determine yield and establish relationship between yield and these traits, which may be useful in selection and adoption.

\section{MATERIALS AND METHODS}

Twenty seven Musa genotypes consisting of plantain and banana hybrids and landraces were used for this study. These included twenty three plantain hybrids: 7152-2, 7152-2 OP15, 15108-6, 23688-2, 23898-3, 23977-7, 24044-3, 24364-S10, 25273-1, 25291-S26, 25291-S32， 25291-S41， 25333-S66, 25333-S88, 25333-S90, 25344-18, 25447-S7, 25502S4, 25729-5, A10-SPS 548-9, A5-SPS 548-9, five banana hybrids: 5295-1, 9128-3, 24408-S22, SH 3362, and two African plantain landraces: Agbagba, and Obino l'Ewai. FHIA stands for Fundación Hondureña de Investigación Agrícola based in Honduras. Bunches were obtained from the experimental station of the International Institute of Tropical Agriculture, High Rainfall Station, Onne, located on Latitude $04^{\circ}$ $43^{\prime} \mathrm{N}$, Longitude $07^{\circ} 01^{\prime} \mathrm{E}$ and $10 \mathrm{~m}$ Altitude, near Port Harcourt, Nigeria. Bunch samples were harvested at full maturity. Three bunches of each cultivar were sampled. Each bunch was weighed with the peduncle attached, but with the male bud and pseudostem cutoff closed to the distal end (last hand) of the bunch. Bunch traits (total number of hands and fruits) were also determined. The number of hands and fruits were obtained by counting the number of hands and fruits on each bunch. Fruits from the second and third hands were used to determine fruit weight and fruit volume. The maturity of hands in the bunch varies slightly: those at the proximal end of the bunch are usually more mature than those at the distal end. The estimate of maturity is based on the fullness of fruit of the middle hand (Thompson and Burden, 1995). Measurements were made immediately after harvest. Fruit weigh and fruit volume was determined using the method described by Dadzie and Orchard (1997). Mean fruit weight was determined by weighing ten different fruits and averaging the weights. The volume of fruit is obtained by direct volume displacement. A $2000 \mathrm{ml}$ (2 litres) measuring cylinder was filled with water, allowing enough space for fruit submersion. A fruit whose weight has been previously determined was then submerged. The final volume was subtracted from the initial volume, to obtain the actual fruit volume. All data analysis was performed using Statistical Analysis Systems (SAS, 1996) software package. Analysis of variance (ANOVA) was used to test for differences among samples. The Least Significant Difference (LSD) Test was employed to separate sample means that were significantly different at $5 \%, 1 \%$ and $0.1 \%$ level of probability.

\section{RESULTS}

Bunch weight and fruit traits at harvest are presented in Table 1 showing considerable genotypic variations in bunch weight and its components. Some of the plantain and banana hybrids performed better than the landraces. Specifically, 25344-18, a plantain hybrid, differed significantly $(\mathrm{P}<0.05)$ from the other hybrids and plantain landraces, with a mean weight of $20.8 \mathrm{~kg}^{-1}$ plant $^{-1}$. Amongst the banana hybrids, bunch weights were considerably higher in SH $3362(19.2 \mathrm{~kg}$ plant $^{-1}$ ) followed by $5295-1$ with $15.9 \mathrm{~kg}^{-1}$ plant $^{-1}$. The least bunch weight was $8.5 \mathrm{~kg}^{-1}$ plant $^{-1}$ for $24408-\mathrm{S} 22$. Two plantain landraces, Obino l'Ewai and Agbagba had bunch weights of 14.7 and $9.1 \mathrm{~kg} \mathrm{plant}^{-1}$, respectively. The mean number of hands bunch ${ }^{-1}$ were higher in the banana hybrids, particularly 9128-3 with 18 hands bunch $^{-1}$ and SH 3362 having 14 hands bunch ${ }^{-1}$ than the other hybrids investigated. These cultivars alongside plantain hybrids 25291-S32 (13 hands bunch ${ }^{-1}$ ), and 25344-18 (11 hands bunch ${ }^{-1}$ ) differed significantly $(\mathrm{P}<0.05)$ with traditional plantains. There was a significant difference $(\mathrm{P}<0.05)$ between the hybrids 9128, SH 3362, 25291-S32 and 25344-18 and local plantains in total number of fruits per bunch.

Comparisons of genotypes for fruit weight and fruit volume are presented in Table 2. Agbagba, a plantain landrace differed significantly $(\mathrm{P}<0.05)$ from the rest of the cultivars both in fruit weight and fruit volume. From the correlation data in Table 3, a high significant positive correlation $(\mathrm{P}<0.01)$ was exhibited between the bunch weight and the number of hands, fruits bunch ${ }^{-1}$, as well as fruit volume. As expected, the 
same trend was observed in the number of hands bunch $^{-1}$ and number of fruit hand ${ }^{-1}$, and between fruit weight and fruit volume. A high negative correlation $(\mathrm{P}<0.01)$ was observed between number of fruit and fruit weight and volume. However, there was no correlation between number of hand and fruit weight, and number of hand and fruit volume.

Table 1. Bunch traits for a selection of Musa hybrids at harvest

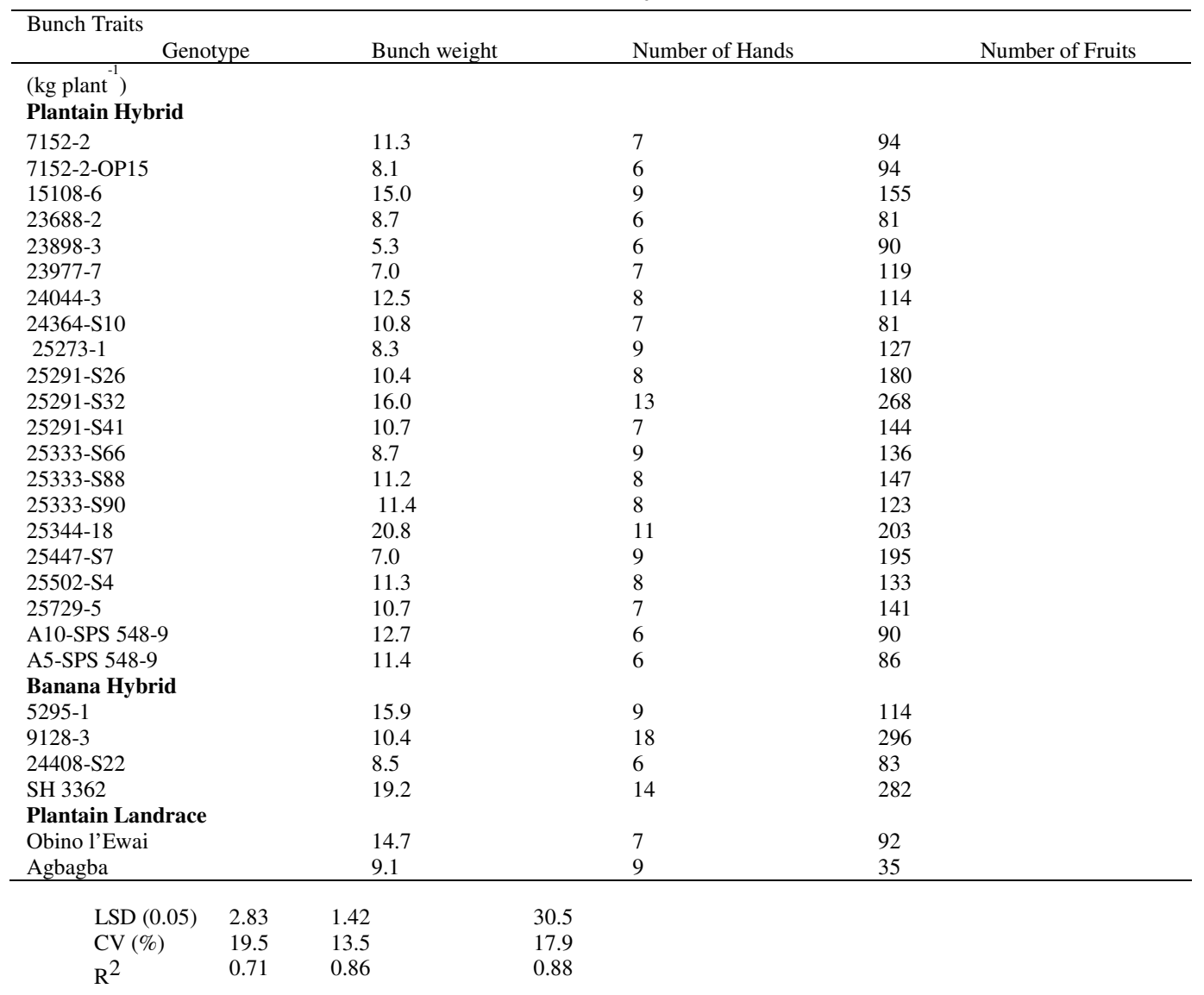

Table 2. Fruit dimensions in Musa spp. hybrid fruit at harvest.

\begin{tabular}{|c|c|c|c|}
\hline Genotype & & \multicolumn{2}{|l|}{ Fruit Traits } \\
\hline \multicolumn{4}{|c|}{ Plantain Hybrid } \\
\hline $7152-2$ & & 150.9 & 156.3 \\
\hline $15108-6$ & & 105.9 & 112.6 \\
\hline $23688-2$ & & 141.5 & 145.8 \\
\hline 23977-7 & & 120.2 & 122.9 \\
\hline 25273-1 & & 88.5 & 91.5 \\
\hline 25291-S41 & & 98.5 & 102.0 \\
\hline 25333-S66 & & 102.0 & 106.0 \\
\hline 25333-S88 & & 106.5 & 109.4 \\
\hline 25447-S7 & & 67.5 & 72.9 \\
\hline 25502-S4 & & 100.8 & 102.5 \\
\hline $25729-5$ & & 126.5 & 130.2 \\
\hline A10-SPS 548-9 & & 201.8 & 205.9 \\
\hline \multicolumn{4}{|l|}{ Banana Hybrid } \\
\hline $5295-1$ & & 240.6 & 246.6 \\
\hline SH 3362 & & 100.7 & 102.3 \\
\hline \multicolumn{4}{|c|}{ Plantain Landrace } \\
\hline Obino l'Ewai & & 164.5 & 170.3 \\
\hline Agbagba & & 361.8 & 352.5 \\
\hline $\operatorname{LSD}(0.05)$ & 17.5 & 17.3 & \\
\hline $\mathrm{CV}(\%)$ & 12.4 & 12.1 & \\
\hline $\mathrm{R}^{2}$ & 0.95 & 0.94 & \\
\hline
\end{tabular}


Table 3. Correlation based on bunch weight and fruit traits for a selection of Musa hybrids at harvest.

\begin{tabular}{|c|c|c|c|c|}
\hline Bunch Traits $^{\mathrm{a}}$ & & & & \\
\hline BWT & $\mathrm{NH}$ & $\mathrm{NF}$ & FWT & FVOL \\
\hline BWT & $0.2480 * * *$ & $0.2731 * * *$ & $0.2268 *$ & $0.3067 * * *$ \\
\hline $\mathrm{NH}$ & & $0.8097 * * *$ & 0.0810 & 0.0763 \\
\hline $\mathrm{NF}$ & & & $-0.5720 * * *$ & $-0.5115^{* * *}$ \\
\hline FWT & & & & $0.9993 * * *$ \\
\hline FVOL & & & & - \\
\hline
\end{tabular}

\section{DISCUSSION}

Post harvest characteristics are essential in the screening of new plantain and banana hybrids, and also provide information that may complement delivery of new accessions to farmers. Plantain hybrid, 25344-18 was the top yielding genotype based on bunch weight among the twenty seven genotypes evaluated. Following the best performing hybrid 25344-18, was SH 3362, a banana hybrid in terms of yield, suggesting the potential for discriminating different Musa hybrids by their yield status where high yielding cultivars may form the basis of adoption and good marketing potential. The top yielding hybrid, 25344-18, was considerably better than its parents (7152-2 and 9128-3) and other hybrids and plantain landraces, which is attributed mainly to heterosis and black Sigatoka disease resistant trait in the new hybrid. This result is in consonance with earlier studies (Ortiz and Vuylsteke, 1996), which showed that some Musa hybrids outperformed their parents in terms of yield. Higher number of hand bunch ${ }^{1}$ exhibited by $25344-18$ coupled with high yield, may be probably linked to heterosis and disease resistance phenomenon, and are clearly very advantageous for new hybrids delivery process. From the results, clone 9128-3 was the best in terms of number of hand bunch- ${ }^{1}$ and number of fruit bunch $^{-1}$, and these traits were apparently retained by plantain hybrid 25344-18, a progeny of 9128-3. The plantain landrace, Agbagba differed significantly $(\mathrm{P}<0.05)$ from other genotypes both in fruit weight and fruit volume. There was a high significant difference $(\mathrm{P}<0.05)$ in fruit weight and fruit volume between banana hybrid, 5295-1 and all other hybrids as well as French plantain landrace, Obino l'Ewai. Highly significant positive correlation $(\mathrm{P}<0.01)$ was observed between bunch weight and the number of hands, number of fruits bunch $^{-1}$, as well as fruit volume. The same trend was observed in the number of hands bunch ${ }^{-1}$ and number of fruit hand ${ }^{-1}$, and between fruit weight and fruit volume. A high negative correlation $(\mathrm{P}<0.01)$ was also observed between number of fruit and fruit weight and volume. However, there was no correlation between number of hand and fruit weight, and number of hand and fruit volume.
Bunch and fruit traits are important because most producers and consumers of plantain and banana usually prefer large size bunch with large or small size fruits and/or long or short fruits, depending on locality or country (Dadzie and Orchard, 1997).

\section{CONCLUSION}

The new plantain hybrid (25344-18) and banana hybrid (SH 3362) with bunch $20.8 \mathrm{Kg}$ plant $^{1}$ and $19.2 \mathrm{Kg}$ plant $^{1}$ respectively, are strongly recommended for adoption based on their bunch weight. The number of hands and fruits bunch ${ }^{1}$ for 9128-3, SH 3362, 25291-S32 and 25344-18 were significantly different $(\mathrm{P}<0.05)$ from plantain landraces (Agbagba and Obino l'Ewai), suggesting better agronomic performance in the new hybrids. Hybrids 9128-3, SH 3362, 25291-S32 and 2534418 with higher number of hands and fruit bunch ${ }^{1}$ may therefore provide fresh fruits for domestic and export markets. The reference cultivar, Agbagba differed significantly $(\mathrm{P}<0.05)$ from the rest of the genotypes both in fruit weight and fruit volume, which provides the need for breeding and agronomic practices to bridge this gap.

\section{ACKNOWLEDGEMENT}

The first author gratefully acknowledge words of inspiration, technical assistance and encouragement from Prof. K.P. Baiyeri of the Department of Crop Science, University of Nigeria, Nsukka, Nigeria.

\section{REFERENCES}

Dadzie, B.K. and J.E. Orchard (1997). Routine Post Harvest Screening of Banana/Plantain Hybrids: Criteria and Methods. INIBAP Technical Guidelines 2. International Plant Genetic Resources Institute, Rome, Italy; International Network for the Improvement of Banana and Plantain, Montpellier, France; ACP-EU Technical Centre for Agricultural and rural Cooperation, Wageningen, The Netherlands. 
Adeniji, Tajudeen Adebayo, Barimalaa, Iminabo Samuel and Tenkouano, Abdou

FAO (1987). Production Yearbook 1986, Rome. Food and Agricultural Organisation of the United Nations.

Ferris, R.S.B., S. Akele, Y.O. Akalumhe and A. Ubi (1994). Distribution and acceptance of ABB cooking bananas in Southeast Nigeria. MusAfrica 5: 9-11.

Fullerton, R.A. (1994). Sigatoka leaf diseases. Pp. 1214 in Compendium of Tropical Fruit Diseases. (Ploetz, R.C. et al., eds). The American Phytopathological Society, St. Paul, Minnesota.

Hahn, S., D. Vuylsteke, and R. Swennen (1990). First reactions to $\mathrm{ABB}$ cooking bananas distributed in southeastern Nigeria. In: R.A. Fullerton and R.H. Stover (eds.). Sigatoka leaf spot diseases of bananas. Proceedings of an international workshop held at San Jose, Costa Rica, March 28April 1, 1989. INIBAP, Montpellier, France.

IITA (1988). IITA Annual Report and Research Highlights 1987/88. Ibadan Nigeria. International Institute of Tropical Agriculture, 161pp.

IITA (1992). Plantains and bananas. In: Sustainable food production in sub-Saharan Africa. International Institutte of Tropical Agriculture (IITA), Ibadan, Nigeria, p. 8691.

INIBAP (1987). Plantain in West and Central Africa. Proposal for Regional Research and Development Network. INIBAP/1987/9. Montpellier, France, International Network for the Improvement of Banana and Plantain.

IPGRI (1999). Annual Report 1998. International Plant Genetic Resources Institute, Rome.

Ortiz, R. and D. Vuylsteke (1996). Improving plantain-and banana- based systems. In: Ortiz, R. and Akoroda, M.O. (eds.). Plantain and Banana: production and
Research in West and Central Africa: Proceedings of a Regional Workshop, held at High Rainfall Station, Onne, Rivers State, Nigeria, Published by the International Institute of Tropical Agriculture (IITA), Ibadan, Nigeria, vii + $166 \mathrm{pp}$.

SAS Institute (1996). SAS Users Guide, Release 6.12 Edition, Statistical Analysis Systems Institute Inc. Cary, North Carolina, USA.

Stover, R. (1983). Effet du Cercospora noir sur les plantains en Amerique centrale. Fruits 38, 326-329.

Stover, R.H. and N.W. Simmonds (1987). Bananas. Tropical Agricultural Series. Third Edition. John Wiley \& Sons, Inc., 605 Third Avenue, New York, NY 10158, pp. 468.

Thompson, A.K. and O.J. Burden (1995). Harvesting and fruit care. In: S. Gowen (ed.). Bananas and Plantains. Chapman and Hall, London, UK, 612pp.

Vuylsteke, D., R. Ortiz, R.S.B. Ferris and J.H. Crouch (1997). Plantain Improvement. Plant Breeding Reviews, 14: 267-320. Jules Janick (ed.). John Wiley \& Sons, Inc. 